\title{
Employment Predictions in Secretarial Occupation
}

\author{
Ali Halıc1 ${ }^{1}$, Burcu Yılmaz ${ }^{1} \&$ Murat Kasımoğlu ${ }^{2}$ \\ ${ }^{1}$ Faculty of Commercial Sciences, Baskent University, Ankara, Turkey \\ ${ }^{2}$ Faculty of Economics and Business Administration, Çanakkale University, Çanakkale, Turkey \\ Correspondence: Ali Halıcı, Faculty of Commercial Sciences, Baskent University, Eskişehir Yolu, 20. Km, \\ Bağlıca Kampusu 06810, Ankara, Turkey. E-mail: ahalici@baskent.edu.tr
}

Received: March 7, 2012 Accepted: June 1, 2012 Online Published: June 19, 2012

doi:10.5539/jms.v2n2p187 URL: http://dx.doi.org/10.5539/jms.v2n2p187

\begin{abstract}
The developments in technology and the intense business life makes secretarial work as an indispensable component of business administration. Besides on the job training and inservice training at workplaces, with the education given at Secretarial Vocational Lycees, at Vocational High Schools and at university levels, quailfied employees are trained. Also the spread of the occupational secretarial courses (on topics such as; touch-type, computer, diction, pre-accountancy) increases the number of qualified personnel.

Although the increase in the number of vocational high schools gives rise to the higher amount of qualified secretaries, the results of the research reveals that the numer of secretaries without vocational education in the occupation is more than the qualified ones in the same field. On the other hand, it is observed that educated secretaries might become unemployed as well.

In this study, determining the employment gap in secreterial vocation by examining the general censuses was aimed.

In the study General Population Censuses which takes place one in five years $(1970,1975,1980,1985,1990$, 2000) were examined. In these populatiun censuses, participants were surveyed about their main occupation and asked what their job was within the last week and the answers given by the citizens were taken into account in this study. Questions that were answered open-ended were classified according to ISCO 88 International Standard Classification of Occupations. The number of graduates of lycees and high schools that are providing secreterial education were taken from The Ministry of Education and Higher Education Board. It was determined that employment gap in secreterial occupation might be closed by the year 2025 according to the projections made.
\end{abstract}

Keywords: secretary, secretarial occupation, emplyment, employment predictions

\section{Conceptual Approaches about the Secretary Profession and Its Importance}

Organizations are composed of elements such as physical, financial and human resources and organize them in order to realize a certain purpose. Human resources are always the foremost of these elements for both public and private organizations. The fact that knowledge has taken the place of materials and energy in manufacturing within the recent process has increased the significance of human resources in information processing skills. Secretaries and administrative assistants have essential roles in organization's human resources. Effective usage of these resources has a great effect on obtaining efficiency and effectiveness. Moreover, secretaries has a bridge function in the communication in and out of the organization and organizational performance in general terms (Tutar, 2002).

As the number of workers who join manufacturing with their labor-power decreases, the need for people who can produce information, develop new inventions and scientific methods, prepare files, write receipts, make organizing plans, market research, sales representation, prepare business letters and use computer efficiently. Effectiveness in organizations requires that all participants should attain the maximum benefit at the beginning and end processes. This requirement increases the importance of secretaries, who are the biggest helpers of administrators, more (Bahş1, 2002).

According to Big Larousse, a secretary is defined as an officer who can ensure communications through steno and type-writer write letters and arrange the corresponding (Bahş1, 2002). 
National Secretaries Association defines a secretary as follows; "An important office person of the work setting, who is the biggest support for the administrator in today's administration of business world, which is getting complicated every day, who provides the opportunity to use communication power, activity gains and the whole working period more effectively" (Altınöz, 1995).

Since secretaries are the first people that the visitors of the organization come across, they are considered as the organization's vision; therefore, it becomes an obligation that they should be more equipped and knowledgeable than the other office employees. For this reason, organizations with today's contemporary management approach increased their expectations from their secretaries and started to desire that they have a different structure (Uygur\& Koç, 2003).

When people working in office services are examined, the first representative of the office is seen to be the secretary, who is almost integrated with the office. While the word "secretary" is used by most institutions, the title administrative assistant has begun to express the position better (Halici\&Delil, 2001).

Today, secretary is the biggest support for the administrator in all levels of management and they are considered as the office workers with the superiority of office competencies, who are capable of taking responsibility without directly being commanded, who can implement the decisions and responsibilities taken, who can take decisions within the limits of her authority, who is self-confident and follows up the necessary precautions towards increasing effectiveness and efficiency, who keep pace with technology and who is regarded as the vision of the organization (Öztoprak, 2006).

Understanding the importance of secretary profession, organizations work with qualified people who are educated on this area and value their work. Secretaries should be at least as knowledgeable as their managers about the business area of the organization and play an active role in communication. They should try to fulfill the secretarial services expected from themselves properly and help both internal and external customers within the scope of his/her authority and responsibility (Bahş1, 2002).

\section{Employment in Secretary Profession}

Employment shows the human power's level of being used, recruiting and working, who are able to participate in the economic activities in a country in a one-year period (Erdoğan, 1986).

Employment is classified as full employment, underemployment and over employment.

"In general terms, the concept full employment refers to the situation where all current production factors in an economy are totally used". However, in economic theory and practice, full employment is defined over one of the production factors, labor. Besides this, it is a mistake that full employment is thought to be a situation where all of the total work force is employed. Several economists accept that a level of employment with a reasonable level of unemployment is full employment considering the temporary or structural elements. Naturally, the rate of unemployment emerging at the level of full employment (frictional unemployment) changes depending on countries and various conditions (http://tr.wikipedia.org/wiki/\%C4\%B0stihdam, May 6, 2007).

Underemployment is not using the production factors in an economy wholly and effectively according to the current technological level. In this case a part of the working-age population cannot find any jobs. In order to increase employment, it is necessary to increase total demand. Hence, firms will increase their sales and the firms that have increased their sales will decide to increase their production, which will in turn increase labor employment.

Overemployment indicates using more production factors than there are in an economy while underemployment refers to the situation that current factors are not used sufficiently. These two conditions are conditions of instability. In the former, borrowing is seen while in the latter, there is unemployment (http://www.ekonomi.name/kavramlar/istihdam.html, May 6, 2007).

\subsection{Areas of Employment Regarding the Secretary Profession in Public Sector}

The graduates of office management and secretary two-year degree programs and occupational high school graduates can work as secretary or office staff in the offices of main service groups as economy, finance, industry, agriculture, education, health, tourism, transportation, religious works, charity works, social security business life, public works and settlement and mining in public sector. Graduates can have active roles in public relations activities and they can also work in Public Economic Enterprises, organizations with circulating capital and local management administrative units. Graduates of undergraduate and graduate programs can work as teachers in commercial high schools and high schools with multiple programs and also as instructors at universities (Coşan, 2003). 


\subsection{Areas of Employment Regarding the Secretary Profession in Private Sector}

While graduates can have jobs as administrative assistant in large organizations, they can also work in document, registration, consultancy, achieve, library and documentation units as well as public affairs units effectively. In small and medium scale business in private sector, graduates mostly work as administrative assistant. Particularly, there is a secretary or assistant staff in small businesses such as law, accounting, real estate offices, insurance, tourism and doctor offices. The graduates are employed under the titles as office manager, administrative secretary, administrative assistant (Coşan, 2003).

\subsection{Resources Supplying Employment}

As a result of continuously increasing world population and the fact that administrative staff positions emerge since the administration of individuals living as a community and the commercial studies develop to medium and large scaled businesses, and that the administrators care more about the concept of efficiency in order to be successful have gradually increased the importance of secretary profession. Administrators' need for an organization and assistant staff in order to be more efficient and successful maintains that secretarial services develop by being within the scope of contemporary management techniques.

Today, secretarial service is an indispensable factor of an administration and the profession has become a respectable, effective branch of occupation which is integrated with management. The secretarial services in our country entered business life for the purpose of ensuring the correspondence, communication and organization works of administrators without a hitch. The fact that business life is intense with a complicated structure increased the need for secretaries and the ones already working in this profession had to renew themselves due to the theoretical knowledge and administrative skills needed. This gives the professional training of the secretary who will provide the services prominence. Besides on the job training and in-service training, currently qualified staff and trainers that can educate qualified staff are trained in the Secretary Occupational High School, vocational high schools and undergraduate and graduate schools. Knowledge, skills and behaviors regarding the profession should be gained both in informal and formal education programs. Moreover, the increase in educational courses (touch-type, computer, diction, pre-accountancy) relevant to secretary profession has increased the number of qualified staff. As a result of the increase in the employer demand for qualified staff and qualified presentations from secretaries, the profession is renewing its image in society in a positive way every day.

As in all occupations, the improvements in technology, business life's requiring expertise, division of new business branches resulted in different working conditions in the secretary profession. Depending on the field of work in the profession, different areas of expertise (medicine secretary, law secretary, financial secretary etc.) can be seen. Skills and knowledge acquired in the profession can be used in areas as public affairs and promotion where human relations are more.

Convenient office coming up with the progress in technology and more efficient office settings facilitate performing the profession and causing knowledge and skills to come to the forefront. Technological developments transform the professional knowledge and skills and the professional setting into a information processing environment rather than instruments such as paper, file, pen etc. The electronic communication and management skills of secretary gradually gain more importance. The requirement that secretaries should follow the technological innovations regarding their profession and gaining information about psychological and working techniques is felt every day. Particularly, the requirement that rapid developments in computer technology should be followed up enriches the meaning of being successful in the philosophy of "continuous professional education".

The general trends in sectors where secretary profession is present, should be considered in terms of the employment status of the work force, changing professional qualifications, innovations regarding technology and organization and customer demands.

\section{Determining the Employment Needs of Secretary Profession}

\subsection{Information Regarding the Research \& the Purpose of the Study}

Today, on the one hand there is lack of capacity that causes the graduates of middle school to be unemployed and on the other hand there is a structure that is a result of the incompliance between education and employment needs, which causes graduates of higher education to be unemployed. As well as this, as stated in the second item of the agreement regarding the place of professional education and guidance in using human resources, which is accepted by ILO in 1975 and by Turkey in 1993, it is necessary that the need for employment in regional and national level, the opportunities and problems should be examined and necessary adjustments 
should be made. Yet, research in literature and state documents couldn't provide any data with regards to the employment needs of a profession.

Therefore, the purpose of the study is to determine the employment gap in secretary profession. By this way, it is put forth how long it is take for the gap determined to be met within the current structure.

\section{Research Method}

In order to determine the current labor force in secretary profession, General Census taken every five years $(1970,1975,1980,1985,1990,2000)$ since 1970 was examined.

- In general census, citizens within the scope were asked about their real occupations and their present job. In the study, answers given by the citizens to these questions were considered.

- Open-ended questions are classified within the scope of ISCO 88 International Occupations Classification.

Under the code 411, secretaries and staff using keyboard are classified.

Data regarding the indicated group are referred as "stenos, typewriters, card punch machine operators" with acronyms in all general census taken between years of $1970-2000$.

\section{Hence, in order to detect the qualified employment:}

- Number of people who stated their real occupation as "secretary" in census was determined.

- $\quad$ Next, the education levels of people who used a statement as; "I am working as a secretary" were examined.

- $\quad$ High school and university graduation were considered for the assessments as "Qualified staff".

- $\quad$ Field of education data regarding high school and university were not included in census so all graduates were assumed to have taken Office Administration and Secretary Education and the maximum number of qualified staff was found out.

- In order to determine the real qualified employment, the gap between the number of total qualified based on real occupation and the number of maximum possible qualified was detected.

- $\quad$ By this way, the difference in being a secretary although no education in the field of Office Administration and Secretary was taken was put forth.

- $\quad$ At the last phase, how this gap has been closed after 2000 was examined.

\subsection{Demographic Data Regarding Secretary Profession in General Census}

The frequencies of people who stated their real occupation and their present job as secretary in general census in terms of age groups and in terms of education level by years according to population groups of state planning organization are classified in below tables.

Table 1. State planning organization's classification distribution in terms of population groups

\begin{tabular}{|c|c|c|c|c|c|c|c|c|}
\hline \multirow[t]{2}{*}{ Years } & \multirow[t]{2}{*}{ Work Status } & \multicolumn{3}{|c|}{$\begin{array}{l}\text { Turkey Total } \\
\text { Total }\end{array}$} & \multicolumn{2}{|c|}{$\begin{array}{l}\text { Villages under } \\
25000\end{array}$} & \multicolumn{2}{|c|}{$\begin{array}{c}\text { Villages over } \\
25000\end{array}$} \\
\hline & & Total & Male & Female & Male & Female & Male & Female \\
\hline \multirow[t]{2}{*}{1970} & $\begin{array}{c}\text { Real } \\
\text { Occupation }\end{array}$ & 27743 & 15019 & 12724 & 6155 & 2330 & 8864 & 10394 \\
\hline & $\begin{array}{l}\text { Present Job } \\
\text { Real }\end{array}$ & 26465 & 14194 & 12271 & 6031 & 2207 & 8163 & 10064 \\
\hline \multirow[t]{2}{*}{1975} & Occupation & & & & & & & \\
\hline & $\begin{array}{l}\text { Present Job } \\
\text { Real }\end{array}$ & 45710 & 23323 & 22387 & 7918 & 2335 & 15405 & 20052 \\
\hline \multirow[t]{2}{*}{1980} & Occupation & & & & & & & \\
\hline & $\begin{array}{l}\text { Present Job } \\
\text { Real }\end{array}$ & 77037 & 31527 & 45516 & 12301 & 6145 & 19247 & 39371 \\
\hline 1985 & Occupation & 104075 & 12282 & 61607 & 15606 & 7700 & 27677 & 53002 \\
\hline
\end{tabular}


As seen in Table 1, according to the population groups of State Planning Organization, 6155 of the people who stated their real job as secretary in 1970 in the classification of villages under 25000 are men and 2330 people are women. According to the classification for cities above 25000,8864 of the people who stated their real job as secretary in 1970 are men and 10394 are women

According to the population groups of State Planning Organization, the highest data in men stating their current job as secretary 15606 in the classification of villages under 25000 and the highest data for women is 7790 in 1985.

According to the population groups of State Planning Organization the highest data in men, who stated their current job as secretary, is 27677 in the classification for cities above 25000 and the highest data in women is 53902 in 1985 (General Population Census, 1970,1975, 1980, 1985: Social and Economical Qualification of the Population, 1973, DİE, Ankara).

Table 2. The age distribution of people stating both their current job and their real occupation as secretary based on census by years

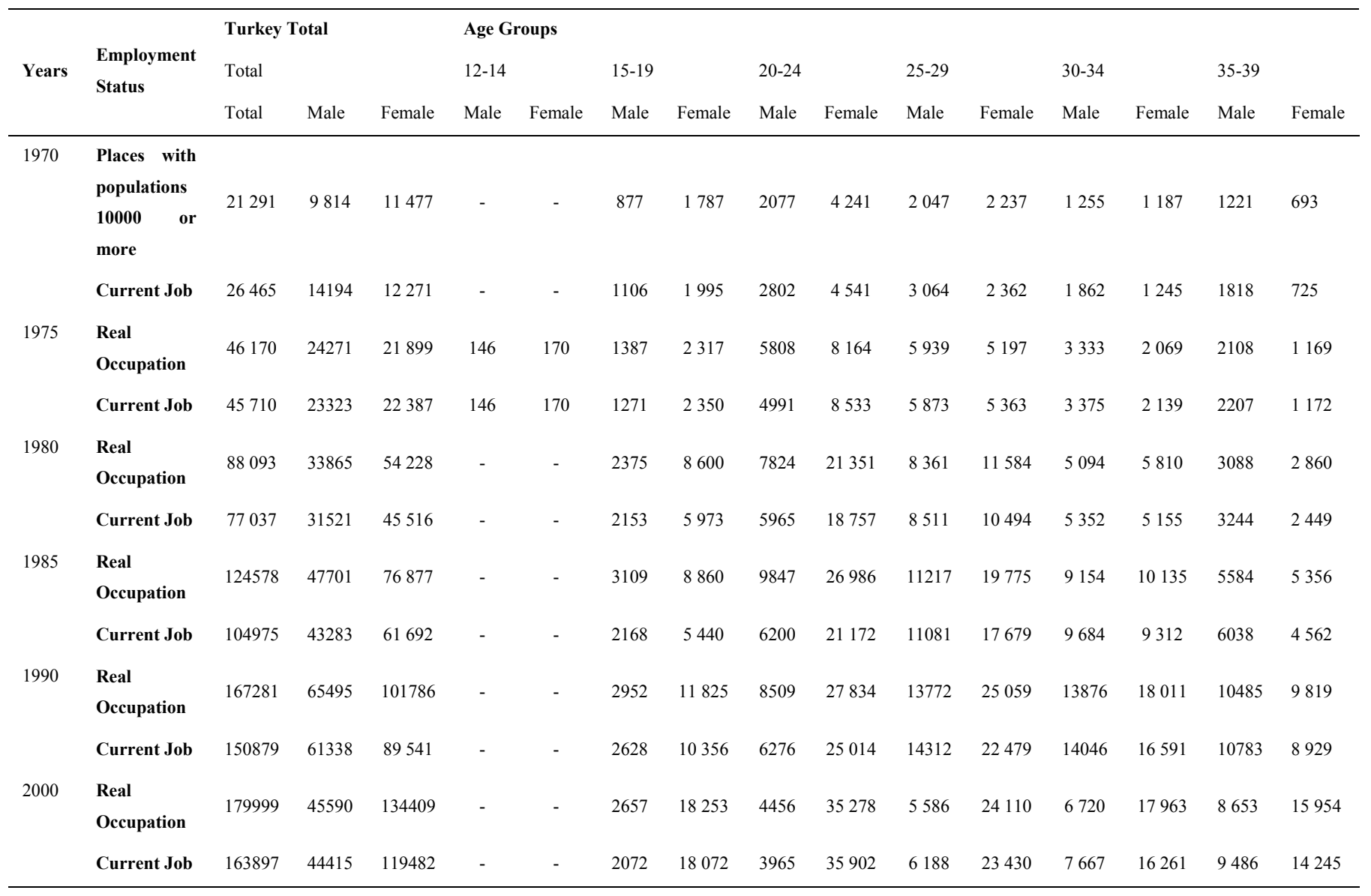


Table 2. Continues

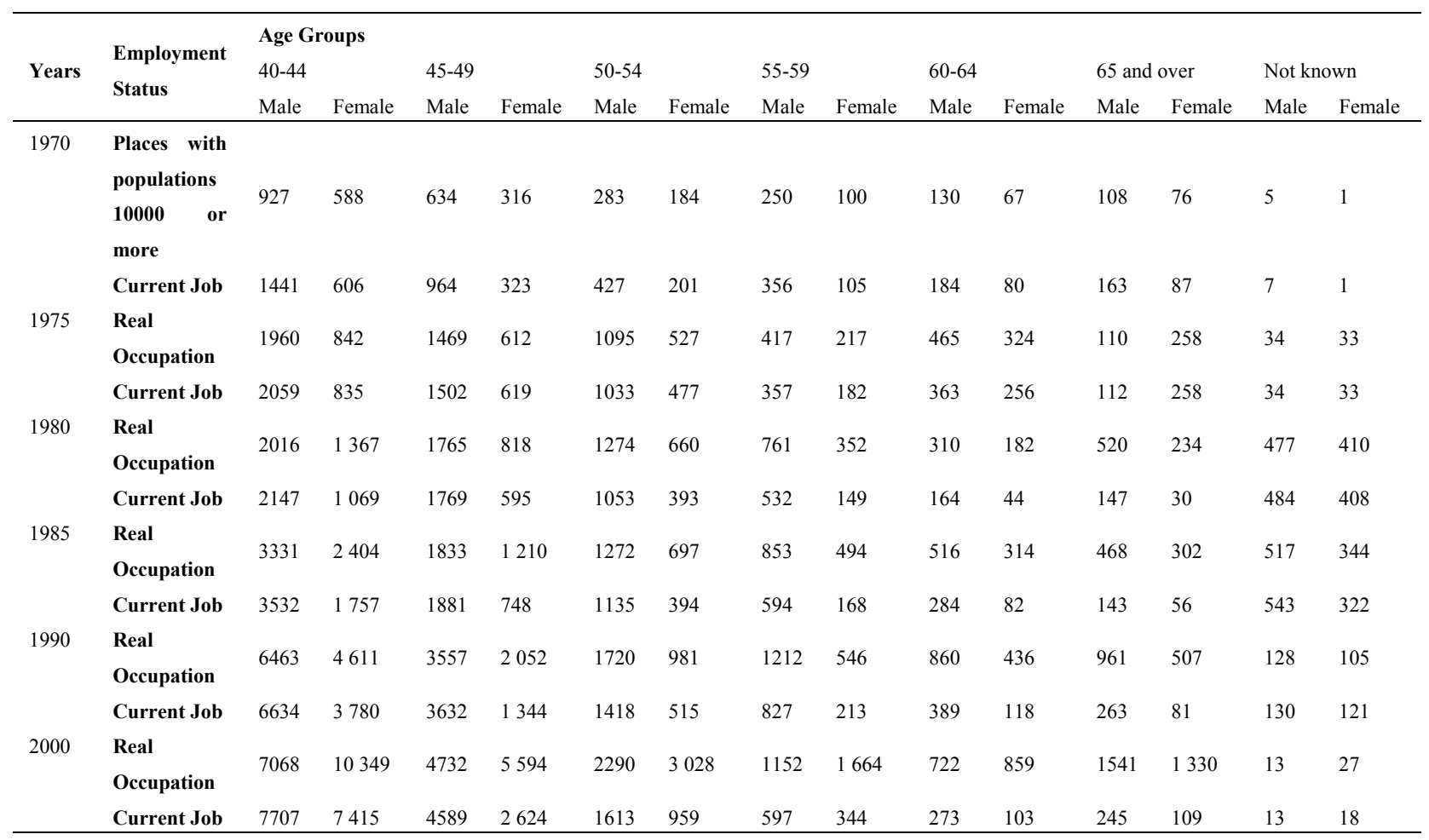

As seen in Table 2, when age groups of people stating their current job and their real occupation as secretary in census by years are considered, it is seen that in 1970 there are 21291 people for places with populations of 10 000 and more. When Turkey total in age groups is considered, it is seen that the highest data in people stating their real job as secretary increased by years and it is found as 179999 people in 2000. The highest data in people stating their current job as secretary increased by years and is found to be 163897 people in 2000 .

According to census by years, when the age groups of people who stated their current job and their real profession as secretary are examined, it is seen that:

- The highest data in people stating their current job as secretary in 1970 is 3064 in men with $25-29$ age group and 4541 in women with $20-24$ age group,

- In 1975 , the highest data in people stating their real occupation as secretary is 5808 in men with $20-24$ age group and 8164 in women with $20-24$ age group. The highest data in people stating their current job as secretary is 5873 in men with $25-29$ age group and 8533 in women with $20-24$ age group,

- In 1980, the highest data in people stating their real occupation as secretary is 8361 in men with $25-29$ age group and 11584 in women with $25-29$ age group. The highest data in people stating their current job as secretary is 8511 in men with $25-29$ age group and 10494 in women with $25-29$ age group,

- In 1985, the highest data in people stating their real occupation as secretary is 11217 in men with $25-29$ age group and 26986 in women with $20-24$ age group. The highest data in people stating their current job as secretary is 11081 in men with $25-29$ age group and 21172 in women with $20-24$ age group,

- In 1990, the highest data in people stating their real occupation as secretary is 13876 in men with $30-34$ age group and 27834 in women with $20-24$ age group. The highest data in people stating their current job as secretary is 14312 in men with $25-29$ age group and 25014 in women with $20-24$ age group,

- In 2000 , the highest data in people stating their real occupation as secretary is 8653 in men with $35-39$ age group and 35278 in women with $20-24$ age group. The highest data in people stating their current job as secretary is 9486 in men with $35-39$ age group and 35902 in women with $20-24$ age group (General Population Census, 1970, 1975, 1980, 1985, 1990, 2000: Social and Economical Qualification of the Population, 1973, DİE, Ankara). 
Table 3. The distribution of people stating both their current job and their real occupation as secretary in census by years in terms of education level

\begin{tabular}{|c|c|c|c|c|c|c|c|c|c|c|c|c|c|c|c|c|}
\hline \multirow[t]{2}{*}{ Years } & \multirow{2}{*}{$\begin{array}{l}\text { Employment } \\
\text { Status }\end{array}$} & Total & \multirow[b]{2}{*}{ Male } & \multirow[b]{2}{*}{ Female } & \multicolumn{2}{|l|}{ Illiterate } & \multicolumn{2}{|c|}{ Literate Total } & \multicolumn{2}{|c|}{$\begin{array}{l}\text { Graduates of a } \\
\text { school }\end{array}$} & \multicolumn{2}{|c|}{$\begin{array}{l}\text { Not graduated from } \\
\text { any institution }\end{array}$} & \multicolumn{2}{|c|}{ Elementary School } & \multicolumn{2}{|c|}{ Primary School } \\
\hline & & Total & & & Male & Female & Male & Female & Male & Female & Male & Female & Male & Female & Male & Female \\
\hline \multirow[t]{3}{*}{1970} & Real & & & & & & & & & & & & & & & \\
\hline & Occupation & & & & & & & & & & & & & & & \\
\hline & Current Job & & & & & & & & & & & & & & & \\
\hline \multirow[t]{3}{*}{1975} & Real & & & & & & & & & & & & & & & \\
\hline & Occupation & & & & & & & & & & & & & & & \\
\hline & Current Job & 45710 & 23323 & 22387 & 329 & 588 & 22963 & 21772 & 22963 & 21772 & 666 & 418 & 10078 & 6149 & 6742 & 6497 \\
\hline \multirow[t]{3}{*}{1980} & Real & & & & & & & & & & & & & & & \\
\hline & Occupation & & & & & & & & & & & & & & & \\
\hline & Current Job & 77037 & 31521 & 45516 & - & - & 31518 & 45514 & 31303 & 45395 & 211 & 109 & 8502 & 6397 & 11056 & 12151 \\
\hline \multirow[t]{3}{*}{1985} & Real & & & & & & & & & & & & & & & \\
\hline & Occupation & & & & & & & & & & & & & & & \\
\hline & Current Job & 104975 & 43283 & 61692 & - & - & 43282 & 61691 & 42957 & 61345 & 313 & 331 & 8616 & 6693 & 12463 & 13149 \\
\hline \multirow[t]{3}{*}{1990} & Real & & & & & & & & & & & & & & & \\
\hline & Occupation & & & & & & & & & & & & & & & \\
\hline & Current Job & 150879 & 61338 & 89541 & - & - & 61337 & 89534 & 61045 & 89207 & 280 & 283 & 10008 & 9686 & 15004 & 15781 \\
\hline \multirow[t]{3}{*}{2000} & Real & & & & & & & & & & & & & & & \\
\hline & Occupation & & & & & & & & & & & & & & & \\
\hline & Current Job & 163897 & 44415 & 119482 & - & - & 44415 & 119482 & 44038 & 118623 & 377 & 859 & 3966 & 13210 & 6092 & 12906 \\
\hline
\end{tabular}

Table 3. Continues

\begin{tabular}{|c|c|c|c|c|c|c|c|c|c|c|c|c|c|c|c|}
\hline \multirow[t]{2}{*}{ Years } & \multirow[t]{2}{*}{$\begin{array}{l}\text { Employment } \\
\text { Status }\end{array}$} & $\begin{array}{l}\text { Middl } \\
\text { Equiva } \\
\text { Vocat } \\
\text { Schoo }\end{array}$ & School & \multicolumn{2}{|c|}{ High School } & \multicolumn{2}{|c|}{$\begin{array}{l}\text { High School } \\
\text { Equivalent } \\
\text { Vocational Schol }\end{array}$} & \multicolumn{2}{|c|}{$\begin{array}{l}\text { Higher Education } \\
\text { and Faculties }\end{array}$} & \multicolumn{2}{|c|}{$\begin{array}{l}\text { Not graduated } \\
\text { from an instiution }\end{array}$} & \multicolumn{2}{|c|}{$\begin{array}{l}\text { Unknown } \\
\text { whether a } \\
\text { graduate or not }\end{array}$} & \multicolumn{2}{|c|}{$\begin{array}{l}\text { Unknown } \\
\text { whether literacy } \\
\text { or not }\end{array}$} \\
\hline & & Male & Female & Male & Female & Male & Female & Male & Female & Male & Female & Male & Female & Male & Female \\
\hline \multirow[t]{3}{*}{1970} & Real & & & & & & & & & & & & & & \\
\hline & Occupation & & & & & & & & & & & & & & \\
\hline & Current Job & & & & & & & & & & & & & & \\
\hline \multirow[t]{3}{*}{1975} & Real & & & & & & & & & & & & & & \\
\hline & Occupation & & & & & & & & & & & & & & \\
\hline & Current Job & 120 & 107 & 4136 & 6456 & 1192 & 2112 & 28 & 30 & 1 & 3 & & & 31 & 27 \\
\hline \multirow{2}{*}{1980} & Occupation & & & & & & & & & & & & & & \\
\hline & Current Job & 145 & 170 & 6755 & 17468 & 3325 & 7147 & 1510 & 2078 & 10 & 24 & 4 & 10 & 3 & 2 \\
\hline \multirow[t]{3}{*}{1985} & Real & & & & & & & & & & & & & & \\
\hline & Occupation & & & & & & & & & & & & & & \\
\hline & Current Job & 47 & 61 & 14448 & 30162 & 5580 & 8341 & 1754 & 2916 & 9 & 23 & 12 & 15 & 1 & 1 \\
\hline \multirow[t]{3}{*}{1990} & Real & & & & & & & & & & & & & & \\
\hline & Occupation & & & & & & & & & & & & & & \\
\hline & Current Job & 58 & 42 & 23850 & 46033 & 8798 & 11864 & 3298 & 5763 & 29 & 38 & 12 & 44 & 1 & 7 \\
\hline \multirow[t]{3}{*}{2000} & Real & & & & & & & & & & & & & & \\
\hline & Occupation & & & & & & & & & & & & & & \\
\hline & Current Job & 179 & 295 & 20145 & 61919 & 7949 & 15678 & 5707 & 14615 & & & - & - & - & - \\
\hline
\end{tabular}


As seen in Table 3, the highest data in people not graduated from an educational institution and who stated their current job as secretary in census by years 666 in men in 1975 and 859 in women in 2000. The people graduated from an educational institution and who stated their current job as secretary increased between the years of 1970 - 2000. However, graduates of an educational institution decreased in men in 2000 compared to 1990 (General Population Census, 1970, 1975, 1980, 1985, 1990, 2000: Social and Economical Qualification of the Population, 1973, DİE, Ankara).

When the level of education of the people who stated their current job as secretary, it is found out that $35 \%$ is a graduate of elementary school in $1975,30 \%$ is a graduate of elementary school in $1980,56 \%$ is a graduate of high school in 1985 and $60 \%$ is a graduate of high school in 1990 and $64 \%$ is a graduate of high school in 2000.

\subsection{The Distribution of People Whose Current Occupation and Real Occupation is Secretary}

Table 4. The number of people whose real occupation and current job is secretary based on census

\begin{tabular}{cccccc}
\hline \multirow{2}{*}{ Year } & \multirow{2}{*}{ Real Occupation } & \multicolumn{2}{c}{ Current Job } & \multicolumn{2}{c}{ Gap } \\
& & Frequency & Percentage & Frequency & Percentage \\
\hline 1970 & 27743 & 26465 & 0.95 & 1278 & 0.05 \\
1975 & 46170 & 45710 & 0.99 & 460 & 0.01 \\
1980 & 88093 & 77037 & 0.87 & 11056 & 0.13 \\
1985 & 124578 & 104975 & 0.84 & 19603 & 0.16 \\
1990 & 167281 & 150879 & 0.90 & 16402 & 0.10 \\
2000 & 179999 & 163897 & 0.91 & 16102 & 0.09 \\
\hline
\end{tabular}

In Table 4, according to data of the year 2000, there are 179.999 people declaring their real occupation as secretary. 163.897 of these stated that they are actively working as secretaries. 1302 of the 16.102 people left are unemployed and 14.800 is working in professions other than secretary. Following the 1985 General Census, it is seen that the gap between current job and real occupation is closed or in contrast not opened (General Population Census, 1970, 1975, 1980, 1985, 1990, 2000: Social and Economical Qualification of the Population, 1973, DIE, Ankara).

\subsection{The Number of Qualified Secretaries Based on the General Census}

In summary in Table 5, even though there seems to be some differences between the real occupation and the current job, the number of qualified staff working as secretaries is $43.949 .27 \%$ of the total employment was educated (General Population Census, 1970, 1975, 1980, 1985, 1990, 2000: Social and Economical Qualification of the Population, 1973, DİE, Ankara).

By 2000 General Census, maximum $24.4 \%$ of the people stating their real occupation as secretary is educated. In other words, $75.6 \%$ of the people claiming their real occupation as secretary haven't been educated.

Table 5. The possible number of maximum qualified secretaries based on the work done in census years

\begin{tabular}{|c|c|c|c|c|c|}
\hline \multirow[t]{2}{*}{ Years } & \multirow{2}{*}{$\begin{array}{l}\text { Total based on } \\
\text { the work done }\end{array}$} & \multicolumn{2}{|c|}{$\begin{array}{l}\text { Possible Maximum } \\
\text { Qualified Number }\end{array}$} & \multicolumn{2}{|c|}{ Employment Gap } \\
\hline & & Frequency & Percentage & & \\
\hline 1970 & 26465 & - & - & - & - \\
\hline 1975 & 45710 & 3362 & 0.07 & 42348 & 0.93 \\
\hline 1980 & 77037 & 14060 & 0.18 & 62977 & 0.82 \\
\hline 1985 & 104975 & 18591 & 0.18 & 86384 & 0.82 \\
\hline 1990 & 150879 & 29723 & 0.20 & 121156 & 0.80 \\
\hline 2000 & 163897 & 43949 & 0.27 & 119948 & 0.73 \\
\hline
\end{tabular}

\section{Results and Suggestions}

Since vocational high school and higher education totals don't have a differentiation based on the type of education offered, all of the graduates of vocational high school were assumed to be qualified secretary and the maximum qualified number was obtained. Accordingly, it was found out that since 1975, number of qualified staff in the sector has increased as seen in Table 2. Particularly after 1990, the increase in vocational high school, 
the newly established universities and occupational high schools educating people to become secretaries caused an increase in the number of qualified secretaries.

In Table 2, it is seen that $15 \%$ of the people in average stating their real occupation as secretary were graduates of occupational high school or vocational school considering the years 1980-1985-1990. This ratio increased to $25 \%$ in 2000 . In contrast, between the years of $1980-1985-1990,85 \%$ of the people in average who stated their real occupation as secretary had a middle school or lower level of education. Hence, these numbers can certainly be implied that they hadn't taken any secretary education at all.

Since 2000, Turkey has experienced growth. More specifically, it was 5.9 in 2000, -9.5 in 2001 and 7.9 in 2002, 5.9 in 2003, 4.9 in 2004 and 7.6 in 2005. Assuming the growth in Turkey would reflect on the employment of secretaries, it is estimated that 206996 people were employed in the sector by 2006 . When the total number of people taken secretary education and graduated, there have been 21212 people from vocational schools, 3261 people from open education faculty, and 2263 people from middle schools since 2000 . Between these years, a total of 26736 qualified secretary started working in the sector. When this number is added with the 43949 possible maximum qualified people, a total of 70685 people could be implied as the maximum qualified people. Considering all numbers, there are 206996 people working as a secretary and $34 \%$ of 70685 of these are qualified. The rest $66 \%$ is working as a secretary although they have no formal education. The number of people working as a secretary although they have no formal education is 136311.

\section{Discussion}

Turkey economically grows at an average of 6-7\% every year. Moreover, 5.400 students are entering into the labour market by completing secretarial education where 4.500 are coming from vocational high schools, 500 from open university and 400 from secondary schools. Despite this, the ratio of qualified secretaries are $34 \%$ in the sector. In other words there is a gap of 140.000 qualified secretaries. Turkey can close this gap in 25 years even if the GDP stays constant. When the average economic growth rate of $6-7 \%$ is considered, the gap will grow at an increasing pace. With this pace of economic growth Turkey has a necessitty of 6.000 new secretaries each year. Even though 6.000 secretaries will be employed as the number of graduates will be 5.400, the gap will keep on increasing.

In this respect, The Ministry of Education should consider taking new measures regarding the number of Secretarial Vocational Lycees. At the same time, new arrangements should be made to increase the capacity of the related programs in vocational high schools.

For the time being, new programs regarding on the job training are a necessity to the 136.000 secretaries which have no vocational education in the sector. Especially, the qualifications of the individuals who are likely to be employed in the secretarial occupations should be determined in the processes of outlining the professional competencies and the necessity of certification should be underlined. Otherwise, this would cause productivity falls and occupational dissatisfaction. And a high rate of turnover emerges for both of the sides- employer and the employee-. The employer who is not happy with the secretary's performance starts looking for new candidates. At the same time, the secretary that has a low level of job satisfaction starts looking for a new job.

In this respect, it is clear that the performance of persons who are doing the job that are educated to do so will be higher. The ways of increasing the qualifications of the individuals employed in the secretarial occupations are to rise the quality and the quantity of the educational institutions and to provide certificates through on the job training programs. The result will come out not only on the personal or corporational scale but also on the social scale by a healthy construction. In the upcoming studies, which educational dimension should be taken priorly can be revealed and educational strategies towards secretarial vocation should be developed.

\section{References}

Altınöz, M. (1995). Günümüz İ̧̧ Ortamında Sekreterlik (1st ed.). Ankara: Yarg1 Pub.Yayınevi.

Bahşı, D. (2002). Türkiye'de Büro Yönetiminde Sekreterliğin Önemi ve Sekreterlik Eğitimine İlişkin Bir Model Önerisi. Unpublisehed Master Thesis. Gazi Üniversity Education Institute, Ankara.

Coşan, P. (2003). Türkiye'de Büro Yönetimi Eğitimi ve Eğitim Programları Hakkında Mezunların Görüsslerinin Saptanması: Bir Alan Çalışması. Unpublisehed Master Thesis.Gazi Üniversity Education Institute, Ankara.

Erdoğan, B. (1986). İstihdam Teorileri ve Türkiye'de İstihdam Sorunu. Unpublisehed Master Thesis, Gazi Üniversity Institute of Social Sciences, Ankara.

General Population Census. (1970). Social and Economical Qualification of the Population, 1973, DİE, Ankara.

General Population Census. (1975). Social and Economical Qualification of the Population, 1978, DİE, Ankara. 
General Population Census. (1980). Social and Economical Qualification of the Population, 1983, DİE, Ankara.

General Population Census. (1985). Social and Economical Qualification of the Population, 1989, DİE, Ankara.

General Population Census. (1990). Social and Economical Qualification of the Population, 1993, DİE, Ankara.

General Population Census. (2000). Social and Economical Qualification of the Population, 2002, DİE, Ankara.

Halıı, A., \& Delil, Y. (2001). Büro Yönetimi Öğrenci ve Mezunlarının Mesleki Algllamalarının Belirlenmesine Yönelik Bir Uygulama. $2{ }^{\text {nd }}$ National Office Management Congress, 8-9 November 2001, Ankara.

Öztoprak, M. (2006). Sekreterlik Bilgisi. (1st ed.). Ankara: Seçkin Pub.

Tutar, H. (2002). Yönetici Sekreterliği. (2nd ed.). Ankara: Nobel Pub.

Uygur, A., \& Koç, H. (2003). Sekreterlik Teknikleri. (1st ed.). Ankara: Detay Pub.

http://www.iskur.gov.tr/mydocu/standart/246.html, 06 Mayıs 2007.

http://tr.wikipedia.org/wiki/\%C4\%B0stihdam, 06 Mayıs 2007.

http://www.ekonomi.name/kavramlar/istihdam.html, 06 Mayıs 2007. 